\title{
Protein solubility as an indicator of overheating rapeseed oilmeal and cake
}

\author{
Barbara Pastuszewska, Lucyna Buraczewska, Anna Ochtabińska \\ and S. Buraczewski
}

\author{
The Kielanowski Institute of Animal Physiology and Nutrition, \\ Polish Academy of Sciences \\ 05-1/0 Jablonna, Poland
}

(Received 7 August 1997; accepted I4 January 1998)

\begin{abstract}
Protein solubility in $0.5 \% \mathrm{KOH}$ and total and available lysine contents were determined in rapeseed meal and cake heated in the laboratory at $130^{\circ} \mathrm{C}$ for $0,10,20,40,80 \mathrm{~min}$, and in 9 meals produced by different oil factories. Protein solubility in the cake decreased due to heating from 89.2 to 44.6 , and in the meal from 58.6 to $43.4 \%$, total lysine content decreased respectively from 6.06 to 5.20 and from 5.85 to $4.96 \mathrm{~g} / 16 \mathrm{~g} \mathrm{~N}$, available lysine from 5.20 to 3.95 and from 4.92 to 3.89 $\mathrm{g} / 16 \mathrm{~g} \mathrm{~N}$. The available lysine content was closely related to protein solubility in the meal heated in the laboratory while no such significant relationship was found in 9 meals processed industrially. The in vivo indices of protein value of meal and cake heated for $0,20,40$ and 80 min, determined with rats, tended to decrease as the heating time was extended from 20 to $40 \mathrm{~min}$, but only in the meal and cake heated for $80 \mathrm{~min}$ and having protein solubility 36.3 and $44.3 \%$, respectively, were all protein value parameters affected significantly. It is concluded that protein solubility in $0.5 \%$ $\mathrm{KOH}$ may be indicative of rapeseed meal overprocessing and cake underprocessing.
\end{abstract}

KEY WORDS: rapeseed meal, rapeseed cake, protein solubility, lysine, protein value, rats

\section{INTRODUCTION}

It has been recognized that overprocessing of soyabean and rapeseed oilmeals reduces their nutritive value for monogastric animals since excess heating decreases protein digestibility and amino acid availability (Baudet et al., 1987; Rakowska et al., 1989; Araba and Dale, 1990; Anderson-Hafermann et al., 1993; Grala et al., 1994). Total and available lysine contents in rapeseed meal are particularly affected both by temperature and duration of heating (Grala et al., 1994) and may be consi- 
dered a good indicator of heat damage to protein. Since analysis of amino acid is expensive and time-consuming, simpler indicators of the degree of overheating solvent meals are being looked for.

Protein solubility in $\mathrm{KOH}$ has been reported to be a good indicator of protein quality in overprocessed soyabean meal (Araba and Dale, 1990; Parsons et al., 1991; Dudley-Cash, 1997), but its usefulness as an indicator of protein quality of rapeseed meal has not been thoroughly evaluated. Using $0.2 \% \mathrm{KOH}$ Goh et al. (1980) measured protein solubility of 14 samples of rapeseed meal and concluded that it was not a reliable index of protein quality. However, the study was performed on meal samples that did not differ significantly in protein quality. In later studies of Anderson-Hafermann et al. (1993) it was found that autoclaving canola meal reduces lysine content, growth performance of chicks and true digestibility of essential amino acids, mostly lysine. Protein solubility in 0.2 and $0.5 \% \mathrm{KOH}$ also decreased as autoclaving time increased, but use of $0.5 \% \mathrm{KOH}$ provided a larger range in solubility values over autoclaving times. The authors conclude that while the reduction in protein solubility due to overheating seems to be smaller in rapeseed than in soyabean meal, $\mathrm{KOH}$ assay may be useful for detecting overprocessed canola meal. Also Rakowska and Ochodzki (1995) in their study of 15 rapeseed cakes and meals of different origin found that protein solubility in $1 \mathrm{M} \mathrm{KOH}$ was closely correlated with true digestibility and biological value of protein for rats. Body weight gain was however correlated with total glucosinolate contents.

The objective of the present study was to determine the usefulness of protein solubility in $\mathrm{KOH}$ as an indicator of the protein value of rapeseed oilmeal and rapeseed cake, especially as a means of identifying overheated RSM having a reduced protein value.

\section{MATERIAL AND METHODS}

Two experiments were performed. In Experiment I the relationship between protein solubility in $0.5 \% \mathrm{KOH}$ and total and available lysine content was determined using samples of rapeseed cake and commercial oilmeal heated for different lengths of time in a laboratory, and in nine meals produced in oil factories in Poland. In Experiment 2 the relationship between protein solubility and protein value for rats of rapeseed cake and oilmeal heated in the laboratory was evaluated.

\section{Material}

Cake and solvent oilmeal produced industrially in the Kruszwica oil factory from the same lot of double low rapeseed were used in the study. Glucosinolate contents was 14.6 and $11.5 \mathrm{mmols} / \mathrm{g}$ DM, respectively. The products were heated 
in the laboratory oven at $130^{\circ} \mathrm{C}$ for $0,10,20,40,60$ and $80 \mathrm{~min}$ in Experiment 1, and for $0,20,40$ and $80 \mathrm{~min}$ in Experiment 2. $100 \mathrm{~g}$ portions of material with equalized moisture level $(18 \%)$ were spread in a $1 \mathrm{~cm}$ layer on aluminum foil, packed tightly and heated for varying lengths of time measured from the moment when the temperature of the material reached $130^{\circ} \mathrm{C}$ (after $15 \mathrm{~min}$ ).

\section{Chemical analysis}

Protein solubility was determined as follows: $1.5 \mathrm{~g}$ sample was stirred with 100 $\mathrm{ml} 0.5 \% \mathrm{KOH}$ for $20 \mathrm{~min}$ and centrifuged at $1250 \mathrm{xg}$ for $10 \mathrm{~min}$. The $\mathrm{N}$ content in the sample and supernatant was analyzed by the Kjeldahl method. Protein solubility in a $0.5 \%$ solution of potassium hydroxide was expressed as a percentage of total protein. Total lysine was determined on a Beckman 6300 amino acid analyzer and available lysine by the method of Booth (1971).

\section{Experiment with rats}

True digestibility (TD), biological value (BV) and net protein utilization (NPU) were determined in a balance experiment performed on $29 \pm 1$ day-old male outbred $I_{2}$ JAZ rats. Growth performance was assayed over 21 days on 24-25 day-old rats of the same origin. The experimental procedure was as described by Smulikowska et al. (1997). The semisynthetic diets used in balance and growth experiments contained rapeseed meal or cake heated for $0,20,40$, and $80 \mathrm{~min}$ as the only source of protein at a level corresponding to $9.5 \% \mathrm{Nx6.25}$. Crude fat content was equalized to $5.0 \%$ by addition of rape seed oil. The diets were supplemented with minerals according to NRC (1976), vitamins according to AOAC (1975), 12\% sucrose and with wheat starch to $100 \%$.

The results of the experiment with rats were subjected to variance analysis using „Statgraph. Plus var. 7" Software. Correlation coefficients and regression equations were calculated.

\section{RESULTS}

\section{Protein solubility and total and available lysine contents}

The effect of prolonged heating on the protein solubility of rapeseed meal and cake was shown in both experiments (Tables 1,3 and 4). Within $80 \mathrm{~min}$, the solubility of meal protein decreased in Experiment 1 from $58.6 \%$ in the non-heated samples to $43.4 \%$ in heated for $80 \mathrm{~min}$, and in Experiment 2 from 57.8 to $36.3 \%$, respectively. Solubility of the non-heated cake was substantially greater and de- 
TABLE 1

Effect of heating rapeseed cake and meal on protein solubility and total and available lysine content (Experiment 1)

\begin{tabular}{|c|c|c|c|c|c|c|}
\hline \multirow[b]{2}{*}{$\begin{array}{l}\text { Heating } \\
\text { time, min }\end{array}$} & \multicolumn{3}{|c|}{ Rapeseed cake } & \multicolumn{3}{|c|}{ Rapeseed meal } \\
\hline & $\begin{array}{c}\text { protein } \\
\text { solubility,\% }\end{array}$ & $\begin{array}{l}\text { total lysine } \\
\mathrm{g} / 16 \mathrm{~g} \mathrm{~N}\end{array}$ & $\begin{array}{c}\text { available } \\
\text { lysine } \mathrm{g} / 16 \mathrm{gN}\end{array}$ & $\begin{array}{c}\text { protein } \\
\text { solubility, } \%\end{array}$ & $\begin{array}{c}\text { total lysine } \\
\mathrm{g} / 16 \mathrm{~g} \mathrm{~N}\end{array}$ & $\begin{array}{c}\text { available } \\
\text { lysine } \mathrm{g} / \mathrm{l} 6 \mathrm{~g}\end{array}$ \\
\hline 0 & 89.2 & 6.06 & 5.20 & 58.6 & 5.85 & 4.92 \\
\hline 10 & 67.7 & 6.00 & 5.13 & 55.0 & 5.80 & 4.64 \\
\hline 20 & 64.0 & 5.92 & 4.99 & 52.6 & 5.70 & 4.57 \\
\hline 40 & 54.2 & 5.78 & 4.74 & 46.7 & 5.38 & 4.43 \\
\hline 60 & 49.4 & 5.45 & 4.44 & 42.9 & 5.07 & 4.02 \\
\hline 80 & 44.6 & 5.20 & 3.95 & 43.4 & 4.96 & 3.89 \\
\hline
\end{tabular}

Protein solubility and total and available lysine contents in rapeseed meals from different oil

TABLE 2 factories

\begin{tabular}{cccc}
\hline $\begin{array}{c}\text { Meal } \\
\text { No }\end{array}$ & $\begin{array}{c}\text { Protein solubility } \\
\%\end{array}$ & $\begin{array}{c}\text { Total lysine } \\
\mathrm{g} / \mathrm{l6g} \mathrm{N}\end{array}$ & $\begin{array}{c}\text { Available lysine } \\
\mathrm{g} / \mathrm{l} \mathrm{gg} \mathrm{N}\end{array}$ \\
\hline 1 & 59.1 & 5.73 & 5.04 \\
2 & 59.0 & 5.97 & 5.00 \\
3 & 55.5 & 5.91 & 4.99 \\
4 & 52.8 & 5.90 & 5.00 \\
5 & 45.9 & 5.73 & 5.10 \\
6 & 47.7 & 5.98 & 4.85 \\
7 & 45.8 & 5.57 & 5.08 \\
8 & 47.2 & 5.80 & 4.70 \\
9 & 48.5 & $5.4 \mathrm{I}$ & 4.75 \\
\hline
\end{tabular}

TABLE 3

Effect of heating rapeseed meal on protein solubility and protein value for rals (Experiment 2)

\begin{tabular}{|c|c|c|c|c|c|c|c|c|}
\hline \multirow{2}{*}{$\begin{array}{l}\text { Heating } \\
\text { time } \\
\text { min }\end{array}$} & \multirow{2}{*}{$\begin{array}{c}\text { Protein } \\
\text { solubility } \\
\%\end{array}$} & \multicolumn{3}{|c|}{ Balance experiment } & \multicolumn{4}{|c|}{ Growth experiment } \\
\hline & & TD & BV & NPU & $\begin{array}{c}\text { feed } \\
\text { intake }\end{array}$ & $\begin{array}{l}\text { body } \\
\text { gain }^{1}\end{array}$ & $\begin{array}{c}\text { feed } \\
\text { conversion }\end{array}$ & $\begin{array}{l}\text { thyroid } \\
\text { weight }^{2}\end{array}$ \\
\hline 0 & 57.8 & $78.9^{\circ}$ & $91.9^{\mathrm{bc}}$ & $72.5^{\text {bc }}$ & $263^{b}$ & $76.4^{\text {: }}$ & $3.47^{\mathrm{ab}}$ & $9.40^{\mathrm{a}}$ \\
\hline 20 & 52.3 & $80.7^{\circ}$ & $90.8^{\text {tri }}$ & $73.3^{\mathrm{bc}}$ & $269^{b}$ & $85.9^{\text {its }}$ & $3.42^{\mathrm{a}}$ & $8.13^{\mathrm{a}}$ \\
\hline 40 & 47.7 & $78.0^{\mathrm{hc}}$ & $88.5^{b}$ & $69.1^{\mathrm{h}}$ & $245^{\text {hc }}$ & $73.9^{\mathrm{h}}$ & $3.84^{\text {ah }}$ & $9.02^{\mathrm{a}}$ \\
\hline 80 & 36.3 & $73.0^{\mathrm{n}}$ & $80.7^{a}$ & $58.7^{\mathrm{a}}$ & $217^{a}$ & 54.]^{c}$ & $4.45^{\circ}$ & $8.16^{\mathrm{a}}$ \\
\hline
\end{tabular}

'per rat $/ 21$ days; ${ }^{2} \mathrm{mg} / 100 \mathrm{~g}$ body weight; a, b, c, $\mathrm{d}-\mathrm{P} \leq 0.05$

clined more rapidly during the first 10 min than that of meal (from 89.2 to 67.7 and from 58.6 to $55.0 \%$, respectively).

Total and available lysine contents were greater in the cake than in the meal, and decreased in both products as the duration of heating was extended (Table 1). In the meal heated for up to $60 \mathrm{~min}$, protein solubility and available lysine content decreased lincarly following a similar pattern (Figure 1) while in the cake, protein solubility seemed to be more affected than lysine (Figure 2 ). 


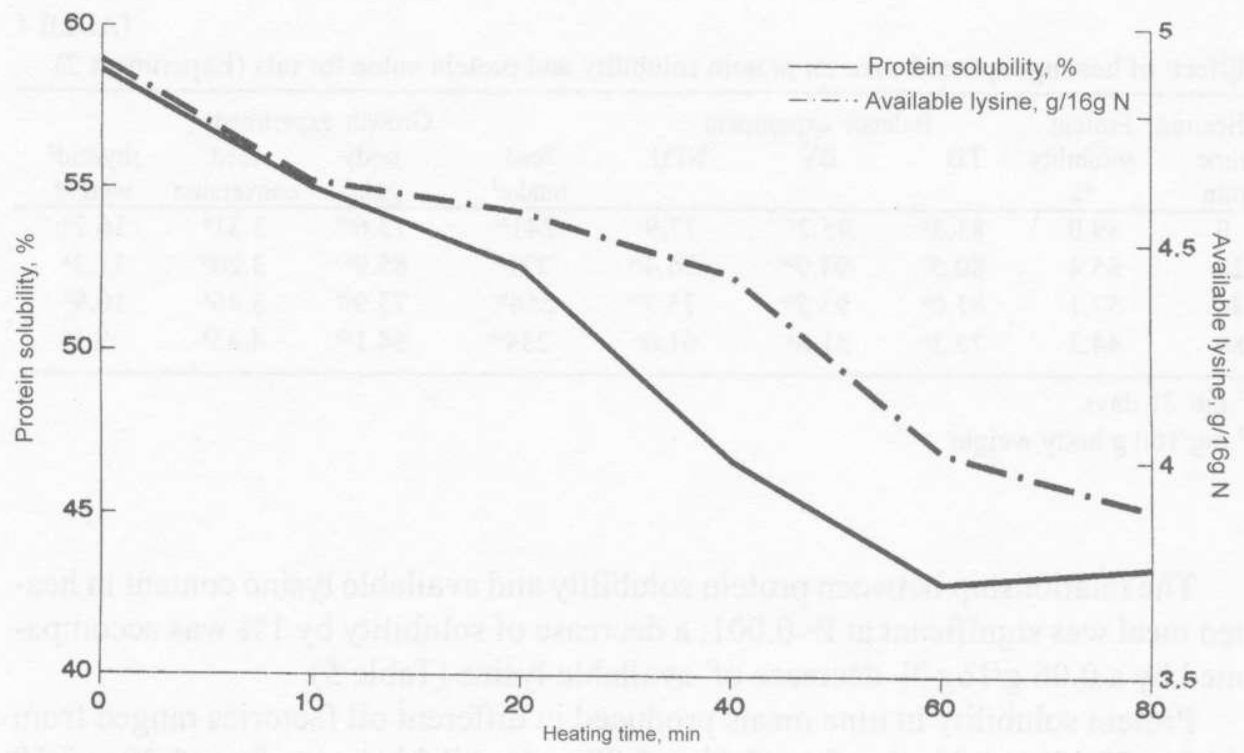

Figure 1. Effect of heating rapeseed meal on protein solubility and available lysine content

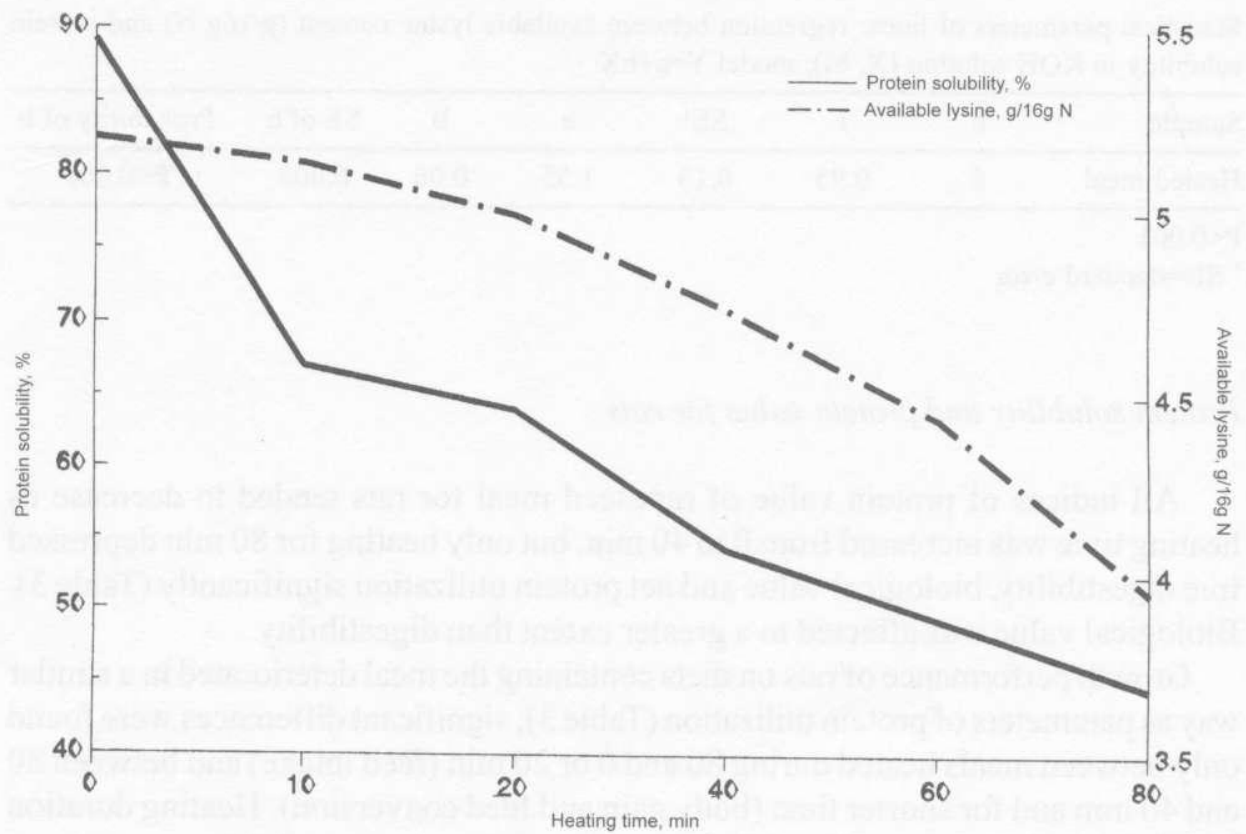

Figure 2. Effect of heating rapeseed cake on protein solubility and available lysine content 
TABLE 4

Effectt of heating rapeseed cake on protein solubility and protein value for rats (Experiment 2)

\begin{tabular}{|c|c|c|c|c|c|c|c|c|}
\hline \multirow{2}{*}{$\begin{array}{l}\text { Heating } \\
\text { time } \\
\text { min }\end{array}$} & \multirow{2}{*}{$\begin{array}{c}\text { Protein } \\
\text { solubility } \\
\%\end{array}$} & \multicolumn{3}{|c|}{ Balance experiment } & \multirow[b]{2}{*}{$\begin{array}{c}\text { feed } \\
\text { intake }^{1}\end{array}$} & \multicolumn{2}{|c|}{ Growth experiment } & \multirow[b]{2}{*}{$\begin{array}{l}\text { thyroid }^{2} \\
\text { weight }\end{array}$} \\
\hline & & TD & BV & NPU & & $\begin{array}{l}\text { body } \\
\text { gain }\end{array}$ & $\begin{array}{c}\text { feed } \\
\text { conversion }\end{array}$ & \\
\hline 0 & 89.0 & $81.3^{b}$ & $95.7^{c}$ & $77.9^{\circ}$ & $241^{\text {bc }}$ & $73.6^{\mathrm{cd}}$ & $3.31^{\mathrm{a}}$ & $16.7^{\mathrm{b}}$ \\
\hline 20 & 65.4 & $80.5^{b}$ & $94.9^{\mathrm{bc}}$ & $76.4^{\mathrm{bc}}$ & $271^{\mathrm{e}}$ & $85.9^{d}$ & $3.20^{\mathrm{a}}$ & $11.3^{\mathrm{a}}$ \\
\hline 40 & 57.1 & $81.0^{\mathrm{b}}$ & $93.5^{\mathrm{bc}}$ & $75.7^{\mathrm{bc}}$ & $254^{b c}$ & $73.9^{\text {cd }}$ & $3.46^{\mathrm{a}}$ & $10.9^{\mathrm{a}}$ \\
\hline 80 & 44.3 & $75.3^{\mathrm{a}}$ & $81.8^{\mathrm{a}}$ & $61.6^{\mathrm{a}}$ & $234^{a b}$ & $54.1^{\mathrm{ab}}$ & $4.45^{b}$ & $9.5^{\mathrm{a}}$ \\
\hline
\end{tabular}

1 rat/ 21 days

${ }^{2} \mathrm{mg} / 100 \mathrm{~g}$ body weight

The relationship between protein solubility and available lysine content in heated meal was significant at $\mathrm{P}<0.001$; a decrease of solubility by $1 \%$ was accompanied by a $0.06 \mathrm{~g} / 16 \mathrm{~g} \mathrm{~N}$ decrease of available lysine (Table 5 ).

Protein solubility in nine meals produced in different oil factories ranged from 45.8 to $59.1 \%$, total lysine from 5.41 to 5.97 and available lysine from 4.70 to 5.10 $\mathrm{g} / 16 \mathrm{~g} \mathrm{~N}$ (Table 2 ). There was no significant relationship between protein solubility and available lysine content.

TABLE 5

Statistical parameters of linear regression between available lysine content $(\mathrm{g} / 16 \mathrm{~g} \mathrm{~N})$ and protein solubility in $\mathrm{KOH}$ solution $(\mathrm{X}, \%)$; model $\mathrm{Y}=\mathrm{a}+\mathrm{bX}$

\begin{tabular}{lccccccc}
\hline Sample & $\mathrm{n}$ & $\mathrm{r}$ & $\mathrm{SE}^{1}$ & $\mathrm{a}$ & $\mathrm{b}$ & $\mathrm{SE}$ of b & Probability of b \\
\hline Heated meal & 6 & 0.95 & 0.13 & 1.55 & 0.06 & 0.008 & $\mathrm{P}<0.001$ \\
\hline
\end{tabular}

$\mathrm{P}<0.001$

${ }^{1} \mathrm{SE}=$ standard error

\section{Protein solubility and protein value for rats}

All indices of protein value of rapeseed meal for rats tended to decrease as heating time was increased from 0 to $40 \mathrm{~min}$, but only heating for $80 \mathrm{~min}$ depressed true digestibility, biological value and net protein utilization significantly (Table 3 ). Biological value was affected to a greater extent than digestibility.

Growth performance of rats on diets containing the meal deteriorated in a similar way as parameters of protein utilization (Table 3 ); significant differences were found only between meals heated during 80 and 0 or $20 \mathrm{~min}$ (feed intake) and between 80 and $40 \mathrm{~min}$ and for shorter time (body gain and feed conversion). Heating duration had no influence on thyroid weight. 
The protein value of the non-heated cake was higher than that of non-heated meal and decreased with heating time to a smaller extent than the value of meal (Table 4). Protein digestibility, biological value and net protein utilization were substantially and significantly lower only for cake heated for $80 \mathrm{~min}$, as compared with cakes heated $40 \mathrm{~min}$ and less.

Growth performance of rats fed on the cake tended to improve insignificantly when the cake was heated for $20 \mathrm{~min}$, and except for feed intake, it was significantly worse in the cake heated $80 \mathrm{~min}$ (Table 5). Thyroid weight was smaller in rats fed on heated than on non-heated cakes.

\section{DISCUSSION}

The results of Experiments 1 and 2 clearly showed that protein solubility in $0.5 \% \mathrm{KOH}$ decreases progressively as rapeseed meal is overprocessed. Similar results were found by Anderson-Hafermann et al. (1993) and Fernandez et al. (1993) for canola meal, and Araba and Dale (1990), Parsons et al. (1991) and DudleyCash (1997) for soyabean meal. In our study the decrease of protein solubility due to heating the meal for $80 \mathrm{~min}$ was smaller than due to autoclaving for $90 \mathrm{~min}$, which was from 52 to 32 and $29 \%$, as reported by Anderson-Hafermann et al. (1993) and Ferandez et al. (1993), respectively. The decrease of protein solubility was accompanied by reduction of both forms of lysine. In the meal heated for 80 min the total lysine content was about $12 \%$ lower while available DFNB-lysine was $26 \%$ lower than in non-heated meal. In the study of Anderson-Hafermann et al. (1993) total lysine concentration was reduced due to autoclaving by $27 \%$, and its digestibility in chicken by 29 units.

In contrast with meals heated in the laboratory, in the meals processed industrially no clear relationship was found between protein solubility and available lysine content, in spite of a similar range of both parameters in the two groups of meals. However, when two outlier industrial meals (Nos. 5 and 7) were excluded, a tendency to lower lysine in meals with lower protein solubility could be observed. The lysine level in industrial meals was also a little higher than in model meals with similar protein solubility. This indicates that protein solubility and available lysine concentration may respond in a somewhat different way to variable technological factors. The negative effect of heating rapeseed meal on total and available lysine concentration, and lysine and protein digestibility is largely attributed to Maillard reaction products formed during toasting (Pickard et al., 1986; Hurrell, 1990; van Soest and Mason, 1991) and depends on time, temperature, moisture and content of reducing sugars in the seeds. All these factors except time were strictly equalized in the model experiments while they may vary between and within oil factories during industrial processing. It seems, therefore, important that the evaluation of protein 
solubility as an indicator of protein value, based on available lysine content, should be established using meals produced under industrial conditions.

Protein solubility in unheated rapeseed cake was substantially greater than in meal, which agrees with the results of Anderson-Hafermann et al. (1993) and Rakowska and Ochodzki (1995). Anderson-Haferman et al. (1993) found that during processing, the solubility of protein in $0.2 \% \mathrm{KOH}$ decreased from $88 \%$ in expeller cake to $42 \%$ in solvent meal. For unknown reasons, the great drop of protein solubility due to solvent extraction does not reflect a small reduction of available lysine content in present work and in the study of Rakowska and Ochodzki (1995) as well as the decrease of lysine digestibility in the study by Anderson-Hafermann et al. (1993). Total and available lysine contents in the cake and meal used in our work were similar to those in the industrially processed expeller cake and meal found by Grala et al. (1994).

In the experiments with rats it was found that while overprocessing of rapeseed meal and cake reduces their protein value, there were no linear relationships between heating time, protein solubility and in vivo indices of protein quality. In Experiment 2 the decrease of meal protein solubility by 10 percentage units, corresponding to the $0.5 \mathrm{~g} / 16 \mathrm{~g} \mathrm{~N}$ decrease of available lysine content in Experiment 1 , did not significantly affect either protein digestibility, biological value, net protein utilization or growth performance of animals. Significant and substantial deterioration of in vivo protein value was found only in the meal heated for $80 \mathrm{~min}$ with a 21.5 percentage units lower protein solubility and available lysine content (extrapolated from the results of Experiment 1) of about $1 \mathrm{~g} / 16 \mathrm{~g} \mathrm{~N}$ less than the unheated sample. Since in Experiment 2 the heating time of 60 min was omitted, it is not possible from the data to determine the threshold value for protein solubility, corresponding to the negative response of animals.

Also in the experiments of Araba and Dale (1990) the weight gain of chickens did not always follow the gradual changes of protein solubility of soyabean meal, while in the Anderson-Hafermann et al. (1993) study, a more consistent decrease of chick performance with the decrease of protein solubility of canola was found. The latter authors came to the conclusion that the $0.5 \% \mathrm{KOH}$ test allows detecting overprocessed canola meal; the meals with low protein solubility have decreased in vivo protein quality. In our study the lack of a marked response to feeding meals heated for less than $80 \mathrm{~min}$ may be explained by the relatively high lysine levels in the non-heated meal and in the meals heated for 20 and $40 \mathrm{~min}$. Although the lysine content in the meals used in the experiment with rats was not determined, it may be assumed that it did not differ from that found in Experiment 1 for respective heating times. Lysine was probably not the limiting factor in low-protein diets containing meals with a total lysine level higher than 5.38 and available lysine higher than $4.43 \mathrm{~g} / 16 \mathrm{~g} \mathrm{~N}$, used as the only source of protein for rats. 
A slight positive effect of short heating rapeseed cake on growth performance may be probably ascribed to the lower levels of thyroid-inhibiting compounds in the cake heated for $20 \mathrm{~min}$ than in non-heated cake, as indicated by reduction of thyroid weight in rats. High protein solubility in rapeseed cake thus points to underprocessing and may be indicative of the presence of glucosinolates in amounts related to levels in raw seeds (Smulikowska et al., 1997).

It should be stressed that a rapeseed meal of high nutritional quality can be obtained only from properly processed seeds with glucosinolate contents below $15 \mu \mathrm{M} / \mathrm{g}$ defatted matter (Rakowska, 1997).

\section{CONCLUSIONS}

Protein solubility in $0.5 \% \mathrm{KOH}$ may be a useful index of overprocessing rapeseed meal and cake, and particularly of lysine damage. Solubility values of $45 \%$ or less are suggestive of rapeseed meal with a lower available lysine content and lower protein value for animals. However, the precise relationships between protein solubility and available lysine and in vivo protein value should be established using meals produced under industrial conditions.

High protein solubility (close to $90 \%$ ) of rapeseed cake may indicate underprocessing and a possible negative effect on the organism depending on the glucosinolate levels in raw material.

\section{REFERENCES}

Anderson-Hafermann J.C., Zhang Y., Parsons C.M., 1993. Effects of processing on the nutritional quality of canola meal. Poultry Sci. $72,326-333$

Araba M., Dale N.M., 1990. Evaluation of protein solubility as an indicator of overprocessing soyabean meal. Poultry Sci. 69, 76-83

Baudet J., Bourdon D., Evrard D. J., Lessire M., 1987. Influence des conditions de cuisson des tourtaux colza sur leur valeur nutritionelle chez le poulet de chair et le proc à l' engrais. Proceedings of 7th International Rapeseed Congress, Poznań (Poland), Vol 7, 1767-1772

Booth V. H., 1971. Problems in the determination of FDNB-available lysine. J. Sci. Food Agric. 22, $658-666$

Dudley-Cash W.A., 1997. Soybean meal quality varies widely in many parts of the world. Feedstuffs $69(6), 15-17$

Fernandez S.R., Zhang Y., Parsons C.M., 1993. Determination of protein solubility in oilseed meals using coomassie blue dye binding. Poultry Sci.72, 1925-1930

Goh Y.K., Clandinin D.R., Robblee A.R., 1980. Protein quality evaluations of commercial rapeseed meals by chemical and biological assays. Can. J. Anim. Sci. 60, 473-480

Grala W., Pastuszewska B., Smulikowska S., Buraczewska L., Gdala J., 1994. Effect of thermal processing on the protein value of double-low rapeseed products. 2. Effect of processing stages in the oil plant and of toasting in laboratory conditions. J. Anim. Feed Sci. 3, 43-55 
Hurrell R. F., 1990. Influence of the Maillard reaction on the nutritional value of foods. In P.A. Finot, H.U. Aeschbacher, R.F. Hurrell (Editors). The Maillard reaction in food processing, human nutrition and physiology. Birkhaüser Verlag, Basel, Switzerland, pp. 245-258

Parsons C.M., Hashimito K., Wedekind K.J., Baker D.H.,1991. Soyabean protein solubility in potassium hydroxide; an in vitro test of in vivo protein quality. J. Anim. Sci, 69, 2918-2924

Pickard M.D., Youngs C.G., Wetter L.R., Bouher G.S., 1986. Processing of canola seed for quality meal. In: D.R. Clandinin (Editor). Canola meat for livestock and poultry. Canola Council of Canada, Publ. 59, 3-4

Rakowska M., 1997. Chemical and biological properties of rape seed glucosinolates (in Polish). Biul. Inst. Hodowli i Aklim. Roślin 201,373-384

Rakowska M., Kupiec R., Sawicki J., 1989. The available lysine content as an index of biological value of double-zero rapeseed oilmeal (in Polish). Thuszcze jadalne, 27, 26-35

Rakowska M., Ochodzki P., 1995. Chemical and biological evaluation of the nutritional value of rapeseed meals obtained with different processing procedures (in Polish). Rośliny Oleiste, 16, 345-349

Smulikowska S., Pastuszewska B., Mieczkowska A. Ochtabińska A., 1997. Chemical composition, energy value for chickens, and protein utilization in rats of rapeseed expeller cakes produced by different pressing technologies. J. Anim. Feed Sci. 6, 109-121

Van Soest P.J., Mason V.C., 1991. The influence of the Maillard reaction upon the nutritive value of fibrous feeds. Anim. Feed Sci. Technol. 32, 45-53

\section{STRESZCZENIE}

\section{Rozpuszczalność bialka jako wskaźnik uszkodzenia termicznego wytloku i śruty rzepa- kowej}

Oznaczano rozpuszczalność białka w $0,5 \% \mathrm{KOH}$ oraz zawartość ogólnej i dostępnej lizyny $w$ wytłoku rzepakowym i śrucie poekstrakcyjnej ogrzewanych w temp. $130^{\circ} \mathrm{C}$ przez $0,10,20,40,60$ i 80 min. oraz w 9 śrutach pochodzących z różnych olejarni. Rozpuszczalność białka w ogrzewanym wytłoku zmniejszyła się z 89,2 do $44.6 \%$, a w śrucie z 58,6 do $43,4 \%$, zawartość lizyny ogólnej odpowiednio z 6,06 do 5,20 i z 5,85 do $4,96 \mathrm{~g} / 16 \mathrm{~g} \mathrm{~N}$, zaś lizyny dostępnej z 5,20 do 3,95 i z 4,92 do $3,89 \mathrm{~g} / 16 \mathrm{~g} \mathrm{~N}$. Zawartość lizyny dostępnej była istotnie skolerowana z rozpuszczalnością białka w śrucie ogrzewanej, natomiast nie stwierdzono takiej zależności w śrutach przemysłowych. Wskaźniki wartości białka, oznaczone na szczurach, miały tendencję do obniżania się w miarę przedtużania czasu ogrzewania z 20 do $40 \mathrm{~min}$, jednak znaczne i istotnie pogorszenie wszystkich wskaźników wartości białka in vivo stwierdzono w przypadku śruty i wytłoków ogrzewanych przez $80 \mathrm{~min}$ i charaktryzujących się niską rozpuszczalnością białka (odpowiednio 36,3 i 44,3\%). Niska rozpuszczalność białka śruty i wytłoku rzepakowego w $0,5 \% \mathrm{KOH}$ może wskazywać na ich uszkodzenie termiczne, natomiast duża rozpuszczalność wytłoku może świadczyć o jego niedostatecznym ogrzaniu. 